\section{BRAZIULIAN JOURNAL \\ OF MEDICAL AND BIOLOGICAL RLSF.ARCH}

www.bjournal.com.br
ISSN 0100-879X

Volume 42 (11) 993-1118 November 2009

BIOMEDICAL SCIENCES

AND

CLINICAL INVESTIGATION

Braz J Med Biol Res, November 2009, Volume 42(11)1035-1038

Effects of different general anesthetics on serum hemolysis and hepatic and muscular glycogenolysis in rats

E.F.A. Machado, A.C.R. Normand, L.A.S. Nunes, R. Brenzikofer and D.V. Macedo

The Brazilian Journal of Medical and Biological Research is partially financed by
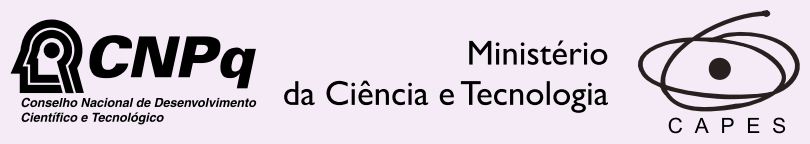

Ministério da Educação

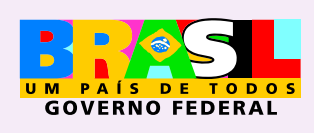

DFAPESP

Institutional Sponsors 


\title{
Effects of different general anesthetics on serum hemolysis and hepatic and muscular glycogenolysis in rats
}

\author{
E.F.A. Machado ${ }^{1 *}$, A.C.R. Normand ${ }^{1 *}$, L.A.S. Nunes ${ }^{1}$, \\ R. Brenzikofer ${ }^{2}$ and D.V. Macedo ${ }^{1}$ \\ ${ }^{1}$ Laboratório de Bioquímica do Exercício, Departamento de Bioquímica, Instituto de Biologia, \\ ${ }^{2}$ Laboratório de Instrumentação em Biomecânica, Faculdade de Educação Física, \\ Universidade Estadual de Campinas, Campinas, SP, Brasil
}

\begin{abstract}
Anesthetics can affect the structure and biological function of tissues and systems differentially. The aim of the present study was to compare three injectable anesthetics generally used in experiments with animals in terms of the degree of hemolysis and glycogenolysis occurring after profound anesthesia. Twenty-four male Wistar rats $(330-440 \mathrm{~g})$ were divided into three groups $(\mathrm{N}=8)$ : chloral hydrate $(\mathrm{CH})$, ketamine + xylazine $(\mathrm{KX})$, Zoletil $50^{\circledR}$ (zolazepam and tiletamine) + xylazine $(\mathrm{ZTX})$. After deep anesthesia, total blood was collected. The liver and white (WG) and red gastrocnemius (RG) muscles were also immediately removed. The degree of serum hemolysis was quantified on the basis of hemoglobin concentration ( $\mathrm{g} / \mathrm{L})$. Hepatic and muscular glycogen concentrations ( $\mathrm{mmol} / \mathrm{kg}$ wet tissue) were quantified by the phenol-sulfuric method. The $\mathrm{CH}$ and $\mathrm{KX}$ groups exhibited serum hemolysis $(4.0 \pm 2.2$ and $1.9 \pm 0.9 \mathrm{~g} / \mathrm{L}$, respectively; $\mathrm{P}<0.05)$ compared to the ZTX group, which presented none. Only $\mathrm{KX}$ induced elevated glycogenolysis (mmol/kg wet tissue) in the liver $(86.9 \pm 63.2)$ and in WG $(18.7 \pm 9.0)$ and RG (15.2 \pm 7.2; $\mathrm{P}<0.05)$. The $\mathrm{CH}$ and $\mathrm{ZTX}$ groups exhibited no glycogenolysis in the liver (164.4 \pm 41.1 and $176.8 \pm 54.4$, respectively), WG $(28.8 \pm 4.4,32.0 \pm 6.5$, respectively $)$ or RG $(29.0 \pm 4.9 ; 25.3 \pm 8.6$, respectively). Our data indicate that ZTX seems to be an appropriate general anesthetic for studies that seek to simultaneously quantify the concentration of glycogen and serum biochemical markers without interferences. ZTX is reasonably priced, found easily at veterinary markets, quickly induces deep anesthesia, and presents a low mortality rate.
\end{abstract}

Key words: General anesthetic; Rats; Glycogenolysis; Hemolysis; Zoletil; Ketamine

\section{Introduction}

Studies on animals often involve the use of various anesthetic types for sample collection, i.e., inhaled agents or agents injectable by the intraperitoneal, intramuscular or intravenous route. Since the anesthetics can affect the structure and function of organs and biological systems in different manners, some effects should be further elucidated. For example, hemolysis is a pre-analytical interfering factor in clinical chemistry (1). Serum concentrations of $\mathrm{Hb}$ above the threshold values can interfere with various biochemical analyses. For human serum, the threshold values are: lactate dehydrogenase $(\mathrm{Hb}>0.2 \mathrm{~g} / \mathrm{L})$, aspartate aminotransferase, potassium and acid phosphate $(\mathrm{Hb}>1.5 \mathrm{~g} / \mathrm{L})$, creatine kinase $(\mathrm{Hb}>2.5 \mathrm{~g} / \mathrm{L})$, alanine aminotransferase $(\mathrm{Hb}$ $>3.4 \mathrm{~g} / \mathrm{L})$, bilirubin $(\mathrm{Hb}>0.8 \mathrm{~g} / \mathrm{L})$, alkaline phosphatase and albumin $(\mathrm{Hb}>1.5 \mathrm{~g} / \mathrm{L})$, and gamma-glutamyltransferase $(\mathrm{Hb}$ $>3.0 \mathrm{~g} / \mathrm{L}$ ) (2). Hepatic and muscular glycogen concentrations can also be depleted depending on the anesthetic used.

An injectable general anesthetic frequently used in studies with animals is chloral hydrate, which, however, produces cardiovascular and breathing depression and can cause blood acidosis (3). The barbiturate pentobarbital is one of the most widely used general anesthetics in studies with animals, its main advantage being its low cost. Pentobarbital has a low analgesic effect and induces breathing depression, also frequently halting breathing before the beginning of surgery (3). The effect of thiopental and pentobarbital administration on biochemical parameters has not been fully explained and there are studies showing interference with

Correspondence: D.V. Macedo, Labex, Departamento de Bioquímica, Instituto de Biologia, UNICAMP, Caixa Postal 6109, $13083-$ 970 Campinas, SP, Brasil. E-mail: labex@unicamp.br

Research supported by CAPES, CNPq, and BIO-100.

${ }^{*}$ These authors contributed equally to this study.

Received March 4, 2009. Accepted September 1, 2009. Available online October 5, 2009. 
glycogen metabolism after their administration $(4,5)$.

Ketamine and tiletamine are two injectable dissociative general anesthetics. Ketamine has analgesic properties, but also seems to affect the cardiovascular system (6). Tiletamine is a more potent anesthetic than ketamine and is used in combination with zolazepam, which is similar to diazepam (7). These two dissociative anesthetics are usually employed in combination with xylazine, which has analgesic, sedative and muscle relaxant effects (7).

The aim of the present study was to compare three injectable anesthetics commonly used in experiments with animals and to examine the degree of serum hemolysis and glycogenolysis in order to determine which would be appropriate for use in studies that need to simultaneously quantify tissue glycogen concentrations and serum biochemical markers without interferences.

\section{Material and Methods}

\section{Animals}

Twenty-four 80-day-old male Wistar rats weighing 330 to $440 \mathrm{~g}$ were housed at $22^{\circ} \mathrm{C}$ under an inverted $12: 12-\mathrm{h}$ light-dark cycle (18:00-6:00 lights on), with free access to laboratory rat chow and water. The experimental protocols were approved by the Ethics Committee for Animal Experimentation of the Universidade Estadual de Campinas (UNICAMP) (Protocol \#1565-1).

The anesthetic concentrations used were tested in a pilot experiment to guarantee that the time to induction of deep anesthesia did not exceed $15 \mathrm{~min}$. On the day of the experiment, the animals were divided at random into three groups, which were subjected to different anesthetic protocols: chloral hydrate $(\mathrm{CH}$; Reagen Quimibrás Chemical Industry S.A., Brazil), $600 \mathrm{mg} / \mathrm{kg}$ weight corresponding to $3 \mathrm{~mL} / \mathrm{kg}$ weight, ip, $\mathrm{N}$

Table 1. Glycogen concentration in hepatic and muscle tissues following treatment with chloral hydrate, ketamine plus xylazine, or zoletil plus xylazine.

\begin{tabular}{lccc}
\hline & $\mathrm{CH}$ & $\mathrm{KX}$ & ZTX \\
\hline Liver & $164.4 \pm 41.1^{\mathrm{a}}$ & $86.9 \pm 63.2^{\mathrm{b}}$ & $176.8 \pm 54.4^{\mathrm{a}}$ \\
White gastrocnemius & $28.8 \pm 4.4^{\mathrm{a}}$ & $18.7 \pm 9.0^{\mathrm{b}}$ & $32.0 \pm 6.5^{\mathrm{a}}$ \\
Red gastrocnemius & $29.0 \pm 4.9^{\mathrm{a}}$ & $15.2 \pm 7.2^{\mathrm{b}}$ & $25.3 \pm 8.6^{\mathrm{a}}$ \\
\hline
\end{tabular}

Data are reported as means \pm SD of tissue glycogen concentration ( $\mathrm{mmol} / \mathrm{kg}$ wet tissue) for 8 animals in each group. $\mathrm{CH}=$ chloral hydrate $(600 \mathrm{mg} / \mathrm{kg}$ weight corresponding to $3 \mathrm{~mL} / \mathrm{kg}$ weight, ip); $\mathrm{KX}=$ ketamine hydrochloride $(100 \mathrm{mg} / \mathrm{kg}$ weight corresponding to $1.16 \mathrm{~mL} / \mathrm{kg}$ weight $)+x y l a z i n e ~ h y d r o c h l o r i d e ~(11 ~ \mathrm{mg} / \mathrm{kg}$ weight corresponding to $0.48 \mathrm{~mL} / \mathrm{kg}$ weight, ip); ZTX = Zoletil $50^{\circledR}(50 \mathrm{mg} / \mathrm{kg}$ weight corresponding to $1 \mathrm{~mL} / \mathrm{kg}$ weight) + xylazine hydrochloride (11 mg/kg weight corresponding to $0.48 \mathrm{~mL} / \mathrm{kg}$ weight, im). Complete anesthesia was achieved closer to 5 min for KX and ZTX groups and $15 \mathrm{~min}$ for the $\mathrm{CH}$ group. Different letters represent significant differences among the groups $(P<0.05$; ANOVA followed by the Tukey post hoc test)
= 8; ketamine hydrochloride (Dopalen, Vetbrands, Brazil), 100 $\mathrm{mg} / \mathrm{kg}$ weight corresponding to $1.16 \mathrm{~mL} / \mathrm{kg}$ weight + xylazine hydrochloride (KX; Anasedan, Vetbrands), $11 \mathrm{mg} / \mathrm{kg}$ weight corresponding to $0.48 \mathrm{~mL} / \mathrm{kg}$ weight, ip, $\mathrm{N}=8$; Zoletil $50^{\circledR}$, $50 \mathrm{mg} / \mathrm{kg}$ weight corresponding to $1 \mathrm{~mL} / \mathrm{kg}$ weight + xylazine hydrochloride (ZTX), $11 \mathrm{mg} / \mathrm{kg}$ weight corresponding to 0.48 $\mathrm{mL} / \mathrm{kg}$ weight, $i m, \mathrm{~N}=8$. The Zoletil $50^{\circledR}$ (Virbac of Brazil, Brazil) anesthetic used contained a 1:1 ratio $(125: 125 \mathrm{mg})$ of tiletamine hydrochloride and zolazepam hydrochloride. The rats were weighed before the anesthesia for calculation of the anesthetic volume to be injected.

All animals were sacrificed at a similar time, from 9:00$11: 00 \mathrm{~h}$, to avoid confounding due to possible hormonal interference with glycogen metabolism (8).

\section{Blood and tissues collection and analysis}

The animals were anesthetized with their respective general anesthetics and kept in individual cages until deep anesthesia was achieved. The corneal, auricular, abdominal clamp, tail clamp, and pedal clamp reflexes were monitored. After complete anesthesia was achieved, closer to $5 \mathrm{~min}$ for $\mathrm{KX}$ and ZTX groups and 15 min for the $\mathrm{CH}$ group, the surgery was started with the opening of the thoracic cavity. Total blood was collected by heart puncture in the left ventricle, stored in Vacuette tubes (Greiner Bio-One, Brazil) with gel and immediately centrifuged at $1800 \mathrm{~g}$ at $4^{\circ} \mathrm{C}$ for $10 \mathrm{~min}$ prior to serum collection. Immediately after blood removal, 35 to 50 mg of liver samples and different portions of the white (WG) and red (RG) gastrocnemius muscle were collected. The tissues were weighed, placed in microtubes, immediately frozen in liquid nitrogen and kept at $-80^{\circ} \mathrm{C}$ for one week. According to previous studies from our laboratory (data not shown), this period of time does not interfere with glycogen concentrations.

The extent of serum hemolysis was determined on the basis of $\mathrm{Hb}$ concentration $(\mathrm{g} / \mathrm{dL})$ using the $\mathrm{Hb}$-cyanide spectrophotometric method with the Drabkin reagent (9). Hepatic and muscle glycogen was also quantified using the spectrophotometric phenol-sulfuric methods proposed by Lo et al. (10).

\section{Statistical analysis}

Statistical significance was set at $P<0.05$. One-way analysis of variance (ANOVA) followed by the Tukey post hoc test was performed using the statistical program Graphpad Instat 3 (GraphPad Software, Inc., USA).

\section{Results}

Measuring $\mathrm{Hb}$ concentration in each anesthetized group, the $\mathrm{CH}$ and $\mathrm{KX}$ anesthetics induced serum hemolysis, with $\mathrm{CH}$ having a higher hemolytic action $(\mathrm{CH}: 4.0$ \pm 2.2 ; $\mathrm{KX}: 1.9 \pm 0.9 \mathrm{~g} / \mathrm{L} ; \mathrm{P}<0.05)$. The serum from the ZTX group did not present hemolysis.

Table 1 presents the hepatic and muscular glycogen 
concentrations of both the white and red portion of the gastrocnemius muscle (mean $\pm \mathrm{SD}$ ) in each anesthetized group. Only the $\mathrm{KX}$ anesthetic induced marked glycogenolysis in liver as well as in gastrocnemius muscle $(P<$ 0.05). We found no effect of $\mathrm{CH}$ or ZTX on tissue glycogen concentrations.

\section{Discussion}

In the present study, different anesthetics applied to Wistar rats were compared regarding the degree of serum hemolysis and tissue glycogenolysis occurring after deep anesthesia. There are several studies in the literature comparing the cardiovascular effects of different anesthetics $(7,11)$. However, few of them analyze their effects on blood biochemical parameters, which could suffer from interference (4). The present study did not quantify any biochemical parameters and therefore we cannot discuss possible interference. Even so, our data facilitate the choice of an anesthetic that does not cause hemolysis (such as ZTX) for studies measuring biochemical parameters.

The $\mathrm{CH}$ anesthetic did not induce glycogenolysis, in agreement with the study of Field et al. (3). However, it did elicit a greater hemolytic effect. The average $\mathrm{Hb}$ concentration in the $\mathrm{CH}$ group samples was visible and above the threshold values of interference for some biochemical analyses (2). It is known that $\mathrm{CH}$ is metabolized quickly as trichloroethanol and trichloroacetic acid in the blood and liver. These metabolites are highly toxic to cells (12). Trichloroacetic acid is a strong acid protein precipitant that causes lipid peroxidation of the cell membranes (13). Lipid peroxidation may be the mechanism underlying the marked hemolysis occurring in the red blood cells of animals anesthetized with $\mathrm{CH}$.

The $\mathrm{KX}$ anesthetic produced about half the hemolysis of $\mathrm{CH}$. On the other hand, $\mathrm{KX}$ produced a sizable muscular and hepatic glycogenolytic reduction compared to $\mathrm{CH}$. Ketamine seems to disturb the integrity of the red blood cell membrane by interacting directly with the glucose carrier (GLUT-1). This interaction inhibits glucose uptake, which could render the cells hypotonic, precipitating hemolysis (14). The glycogenolytic effect may be related to increasing catecholamine release due to activation of the sympathetic nervous system that seems to occur soon after the administration of this drug (15). It is not possible to rule out a direct action of $\mathrm{KX}$ on some enzymes involved in glycogen metabolism (15).

\section{References}

1. Lippi G, Blanckaert N, Bonini P, Green S, Kitchen S, Palicka $\checkmark$, et al. Haemolysis: an overview of the leading cause of unsuitable specimens in clinical laboratories. Clin Chem Lab Med 2008; 46: 764-772.
Xylazine is an alpha-2 adrenergic agonist that can cause hyperglycemia in some animals, contributing to a glycogenolytic action when combined with ketamine. Rodrigues et al. (16) found much higher values of blood glucose in rats anesthetized with $\mathrm{KX}$ when compared with rats anesthetized with $\mathrm{CH}$, suggesting hepatic glycogenolysis. In contrast, Musch et al. (17) did not observe alterations in glycogen concentration after $\mathrm{KX}$ administration. However, the method used to induce deep anesthesia involved a lower dose of anesthetic (ketamine: $50 \mathrm{mg} / \mathrm{kg}$ weight and xylazine: $3 \mathrm{mg} / \mathrm{kg}$ weight), combined with gas maintenance ( $70 \%$ nitric oxide and $30 \%$ oxygen). It is thus likely that the lower concentration of anesthetic resulted in less activation of the sympathetic nervous system.

ZTX is a combination of tiletamine-zolazepam-xylazine and proved to be the most appropriate of the anesthetics for studies that require the simultaneous quantification of the concentration of glycogen and serum biochemical markers without interferences. Although tiletamine alone activated the sympathetic nervous system and tended to induce convulsive activity (18), it was efficient when administered with zolazepam, which possesses anticonvulsive, anxiolytic, sedative-hypnotic, and muscle relaxant properties $(7,18)$. When administered together, these anesthetics induced neither hemolysis nor glycogenolysis immediately after the deep anesthesia. This combination of compounds has been used as a tranquilizer to immobilize wild animals $(7,19)$. Furthermore, many studies have already demonstrated its effectiveness in anesthetizing rats and other animals $(7,18-20)$. In a comparative study of ketamine-xylazine, pentobarbital and tiletamine-zolazepam, the last caused fewer cardiovascular effects in rats when compared to the others (11). In another study, it was shown that ketamine-xylazine resulted in faster breathing rates and higher arterial $\mathrm{O}_{2}$ partial pressure than tiletamine-zolazepam-xylazine (20).

In the present study, we used the commercial anesthetic Zoletil $50^{\circledR}$, which is a combination of tiletamine-zolazepam and xylazine, to cause deep anesthesia, analgesia, sedation, and efficient muscle relaxation prior to surgery $(7,19,20)$. This combination also decreased the final cost, because it reduced the Zoletil $50^{\circledR}$ concentrations required.

ZTX seems to be an appropriate anesthetic to be used in research with laboratory animals. The cost of this method is reasonable, especially since it does not require an inhaler. Moreover, the compound is commonly found at veterinary markets, can be applied with ease, induces deep anesthesia quickly, and presents a low mortality rate.

2. Grafmeyer D, Bondon M, Manchon M, Levillain P. The influence of bilirubin, haemolysis and turbidity on 20 analytical tests performed on automatic analysers. Results of an interlaboratory study. Eur J Clin Chem Clin Biochem 1995; 
33: $31-52$.

3. Field KJ, White WJ, Lang CM. Anaesthetic effects of chloral hydrate, pentobarbitone and urethane in adult male rats. $L a b$ Anim 1993; 27: 258-269.

4. Gonzalez GA, Silvan G, Illera JC. Effects of barbiturate administration on hepatic and renal biochemical parameters in New Zealand white rabbits. Contemp Top Lab Anim Sci 2005; 44: 43-45.

5. Penicaud L, Ferre P, Kande J, Leturque A, Issad T, Girard J. Effect of anesthesia on glucose production and utilization in rats. Am J Physiol 1987; 252: E365-E369.

6. Heavner JE. Pharmacology of analgesics. In: Kohn DF, Wixson SK, White WJ, Benson GJ (Editors), Anesthesia and analgesia in laboratory animals. New York: Academic Press; 1997. p 8-10.

7. Lin HC, Thurmon JC, Benson GJ, Tranquilli WJ. Telazol - a review of its pharmacology and use in veterinary medicine. $J$ Vet Pharmacol Ther 1993; 16: 383-418.

8. Saubert CW, Armstrong RB. Hormonal influence on diurnal glycogen rhythms in rat skeletal muscles. J Exp Biol 1983; 102: $285-293$

9. Morris MW, Davey FR. Exame básico de sangue. In: Henry JB (Editor), Diagnósticos clínicos e tratamentos por métodos laboratoriais. 19th edn. São Paulo: Manole; 1999.

10. Lo S, Russell JC, Taylor AW. Determination of glycogen in small tissue samples. J Appl Physiol 1970; 28: 234-236.

11. Saha DC, Saha AC, Malik G, Astiz ME, Rackow EC. Comparison of cardiovascular effects of tiletamine-zolazepam, pentobarbital, and ketamine-xylazine in male rats. J Am Assoc Lab Anim Sci 2007; 46: 74-80.

12. Lipscomb JC, Mahle DA, Brashear WT, Garrett CM. A species comparison of chloral hydrate metabolism in blood and liver. Biochem Biophys Res Commun 1996; 227: 340-350.
13. Celik I, Isik I. Determination of chemopreventive role of Foeniculum vulgare and Salvia officinalis infusion on trichloroacetic acid-induced increased serum marker enzymes, lipid peroxidation and antioxidative defense systems in rats. Nat Prod Res 2008; 22: 66-75.

14. Stephenson KN, Croxen RL, El-Barbary A, Fenstermacher JD, Haspel HC. Inhibition of glucose transport and direct interactions with type 1 facilitative glucose transporter (GLUT1) by etomidate, ketamine, and propofol: a comparison with barbiturates. Biochem Pharmacol 2000; 60: 651-659.

15. Ivankovich AD, Miletich DJ, Reimann C, Albrecht RF, Zahed B. Cardiovascular effects of centrally administered ketamine in goats. Anesth Analg 1974; 53: 924-933.

16. Rodrigues SF, de Oliveira MA, Martins JO, Sannomiya P, de Cassia TR, Nigro D, et al. Differential effects of chloral hydrate- and ketamine/xylazine-induced anesthesia by the s.c. route. Life Sci 2006; 79: 1630-1637.

17. Musch TI, Warfel BS, Moore RL, Larach DR. Anesthetic effects on liver and muscle glycogen concentrations: rest and postexercise. J Appl Physiol 1989; 66: 2895-2900.

18. Kohn DF, Wixson SK, White WJ, Benson GJ. Anesthesia and analgesia in laboratory animals. New York: Academic Press; 1997.

19. Sweitzer RA, Ghneim GS, Gardner IA, Van Vuren D, Gonzales BJ, Boyce WM. Immobilization and physiological parameters associated with chemical restraint of wild pigs with Telazol and xylazine hydrochloride. J Wildl Dis 1997; 33: 198-205.

20. Popilskis SJ, Oz MC, Gorman P, Florestal A, Kohn DF. Comparison of xylazine with tiletamine-zolazepam (Telazol) and xylazine-ketamine anesthesia in rabbits. Lab Anim Sci 1991; 41: 51-53. 